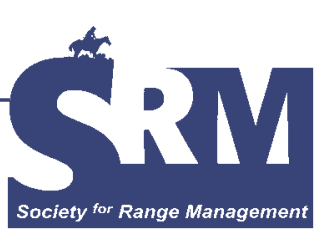

\title{
Nevada Rangelands
}

\section{By James A. Young and Charlie D. Clements}

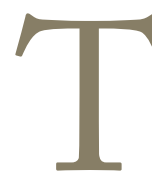

he State of Nevada contains about 110,000 square miles of various rangeland environments. Much of this rangeland is desert. There is a tiny amount of tall timber forest along the west central border where Nevada touches the eastern slope of the Sierra Nevada. At one time the College of Agriculture of the University of Nevada Reno had 2 foresters on staff and they had to share a tree. On the highest mountain ranges, especially in the eastern portion of the state, 5-needle pine woodlands of bristle cone and limber pine occur magnificently, but sparingly. Nevada does have extensive single leaf pinyon-Utah juniper woodlands. These mid-mountain slope woodlands occur below the 5-needle pines and above the sagebrush/bunchgrass zone. The classic practical joke to which neophyte graduate students are subjected is to send them to the field to collect a specimen of "pinyon juniper." With affinity to the Colorado Plateau and the mountains of the southwest, the Nevada pinyon-juniper woodlands are most abundant south of Interstate 80 that crosses the state diagonally from Reno to Wendover on the Utah-Nevada state line. In northwestern Nevada, the mountain ranges have occasional small stands of Utah or western juniper, but some ranges with substantial higher elevation areas, such as the Santa Rosa in Humboldt County northwest of Winnemucca, are virtually without trees except for aspen and cottonwoods.

If Nevada is long on rangeland and short on forest environments, what characterizes the rangelands? To understand the vegetation you have to appreciate the structural geology and recent geological history. Yes, Nevada is in the Great Basin from which there is no drainage to the ocean. There are exceptions in the north where one fork of the Owyhee River and Salmon Falls Creek contribute to the Snake-Columbia watershed. Likewise in the south the Virgin and Muddy Rivers are tributaries of the Colorado River. The rest of the state has an internal drainage system. This does not mean the Great Basin is a gigantic bowl surrounded by mountains with everything draining to the center. If you climb one of the numerous mountain peaks in central Nevada and turn $360^{\circ}$ admiring the landscape, you cannot help but be impressed that Nevada is nothing but continuous mountain ranges. Go to the center of one of the large basins such as the northern Carson Desert and Nevada appears to be an endless, nearly perfectly flat plain with smudges on the horizon that shimmer in the heat wave and resemble mountains.

Actually, both impressions are real. In Nevada there are more than 200 separate mountain ranges. They tend to be orientated north and south and often stand independently with no or minimum contact among ranges. A 19th century geologist described the independent mountain ranges as "a series of caterpillars marching off to Mexico." Arranged in echelon, these mountains allow for the passage of trails, highways, and railroads without climbing mountain passes. This line of least resistance for transportation routes works as long as you approach the mountains diagonally. This is the route of old US Highway 40 (now Interstate 80) from Reno to Salt Lake City, Utah. Only one significant summit has to

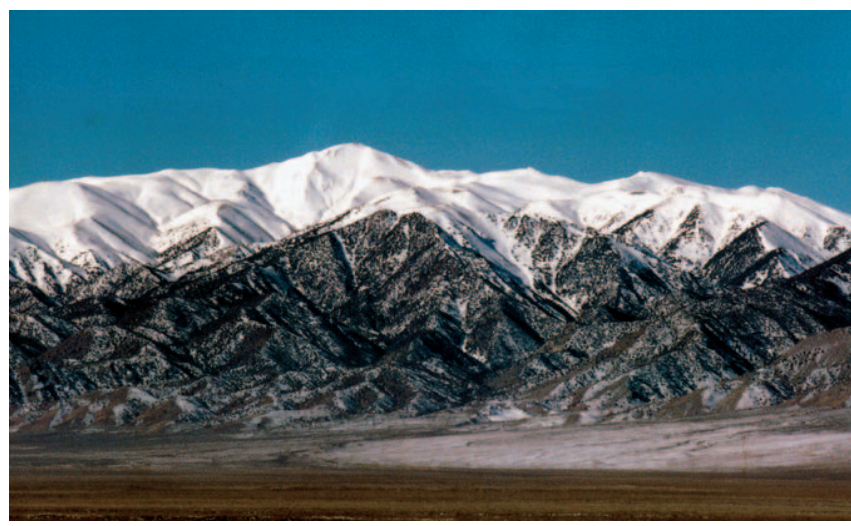

Mount Augusta in the Clan Alpine range of west central Nevada rises above the valley floor at 9,966 feet in elevation. The higher elevations are mountain brush communities. The middle portion of the mountain escarpment supports single leaf pinyon/Utah juniper woodlands. The alluvial fans at the base of the mountain support Wyoming big sagebrush/ Thurber's needlegrass/shadscale communities. The lake plain below the fans has a black greasewood, basin big sagebrush-salt rabbitbrush/basin wildrye community. 
be crossed on this route. US Highway 50 from Reno to the Utah line runs perpendicular to the mountain ranges and you cross 12 named summits, 7 of which are above 7,000 feet.

The Nevada mountain ranges stand as islands of environmental potential for plant growth in a sea of aridity. Moisture for the western Great Basin comes almost entirely from the Pacific Ocean and falls during the cold winter months. As you proceed south and east, summer monsoonal moisture sources weakly contribute to the moisture regime. Just before or early in the Pleistocene, the Sierra Nevada and Cascade Mountain ranges began a precipitous rise that produced a near continuous western mountain barrier which intercepts moisture-laden winds from the Pacific and cast rain shadows across the western Great Basin. During the Pleistocene, slightly higher precipitation and markedly reduced evaporation with cooler temperatures combined to change the water balance of the Great Basin. The many internal basins partially filled with water to form substantial lakes. Some basins spilled to create rivers that generally drained to the lower elevations in the north central portion of what is now Nevada. A vast lake formed in this area that would rival the current Great Lakes in surface area. It was named by 19th century geologists as pluvial (referring to previous wetter times) Lake Lahontan. Lake Lahontan was contemporary with pluvial Lake Bonneville (current Great Salt Lake). Unlike Lake Bonneville, Lake Lahontan never breached the surrounding mountain rim and partially drained to the ocean. This means that the soluble salts that were washed into Lake Lahontan remained within the basin. This has led to the basin vegetation of $\mathrm{Ne}-$ vada commonly being identified as "salt desert."

The aridity of the Holocene that replaced the Pleistocene resulted in the near complete desiccation of the pluvial lakes. This aridity has left many of the physical features of the pluvial lakes such as wave-cut beach ridges, offshore bars, and wave plunge pit lagoons frozen in time. The most striking pluvial lake feature that remains is the playas. A misapplication of the Spanish word for beach, the playas represent exposed deep-water sediments with fine clay textures. The playa surface typically has a polygonal pattern which Israel Cook Russell (who first described Lake Lahontan) likened to the texture of the finest Italian marble. Playa surfaces are bare, except for occasional sand or mud (clay particles cemented to salt crystals) dunes that may support black greasewood plants. There are many varieties of playa surfaces depending on the age, hydrology, and basin geology, but the common occurrence is for the surface to be coated with dazzling salt crystals left by capillary rise after a moisture event. The salts, including sodium, chlorine, and highly phytotoxic ions of boron and lithium, are eroded by winds and redeposited to the lee of the playas. Soil scientist Robert Blank has determined that through the process of erosion and the deposition of fine-textured sediments, the playas have an influence on the environment much larger in scale than the area of the playa itself, which is a substantial $5 \%$ of the total northern Nevada landscape. The fine silts that are wind eroded off the playas play a major part in soil development in the uplands where they are deposited.

The area on the basin floors surrounding the playas has 3 basic plant assemblages: 1) black greasewood, 2) shadscale, or 3) sand vegetation communities. Black greasewood communities range from nearly pure black greasewood on the most salt-affected soils to mixtures of black greasewood, basin big sagebrush, and salt rabbitbrush. Such communities often alternate with shadscale. Bruce Roundy determined that the black greasewood communities are largely phreatophytic, with the shrubs rooted to the water table which may be located at considerable depths below the surface. At some time in the existence of the community, the water table had to reach the soil surface where the shrubs established and their roots then followed the descending water table. In the shadscale alterns, the dominate shrub is dependent on rainfed moisture in an environment where the annual depth of soil wetting ranges from near zero to 8 to 10 inches. There is no connection between the roots of these plants and the groundwater table.

The glacial rivers that fed Lake Lahontan provided the source of sand for the dunes and fields that are an important component of the lake plain environment. Sands of the northern Nevada basins are highly permeable so that even the moisture of occasional high-intensity summer thunderstorms are not lost by overland flow. In contrast, the fine-textured lake plain soils are so impermeable that skiffs of winter snow are lost to sublimation while only slightly wetting the soil surface. The permeability of the sands leads to leaching of soluble salts in an environment where virtually all other soils are highly influenced by such salts. Only a very small percentage of the sands are devoid of vegetation with actively moving dunes. Silver State Valley in Humboldt County and Sand Mountain in Churchill County are exceptions.

There are 2 native plant communities of the Nevada basins that have great significance to the range livestock in-

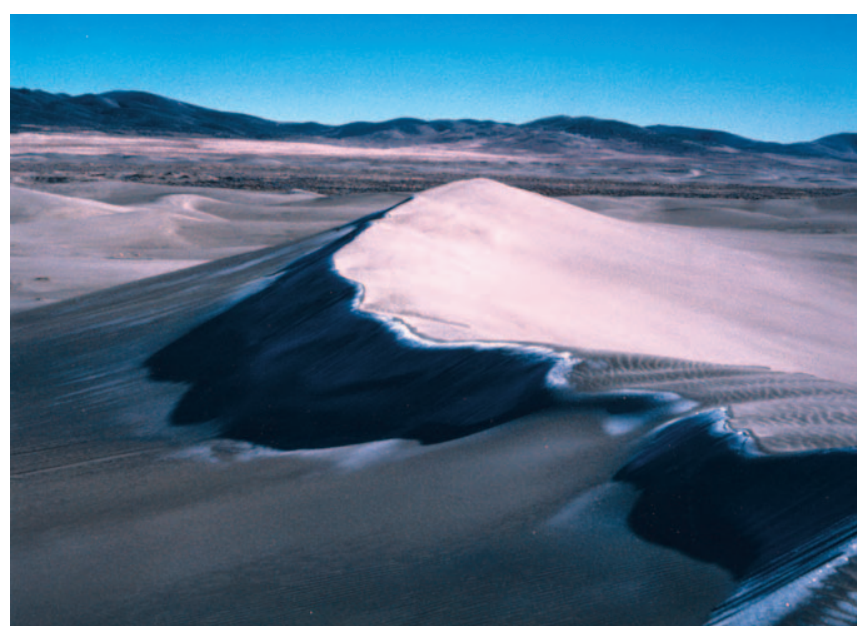

The glacial rivers that fed pluvial Lake Lahontan dumped large amounts of sand. The combination of prevailing winds has eroded the sands to the northeast during the holocene, as witnessed here near Winnemucca, Nevada. 


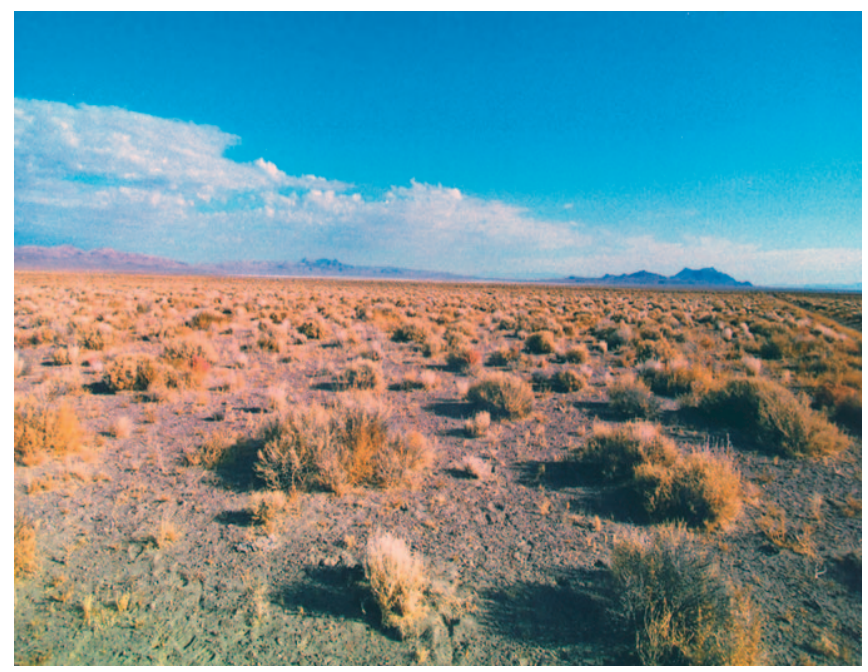

The Forty Mile Desert as seen by early pioneers bound for California. In the mid-19th century hundreds of California-bound emigrants died on this portion of the trail. In the middle of Nevada basins the mountain ranges seem insignificant in the landscape, yet you are surrounded by an endless near-flat plain with very sparse water resources. The vegetation is Bailey's greasewood, shadscale and two very important winter grazing species, Indian ricegrass and winterfat.

dustry. Indian ricegrass and needle-and-thread grass can be very abundant on the sand areas and on specific portions of the fine-textured soils and the native half shrubs winterfat and budsage grew in near monospecific abundance. Standing cured Indian ricegrass, which retains a portion of its seed in its heads over winter, and winterfat combine to provide bulk and digestible protein for wintering livestock. Budsage is an extreme ephemeral species that provides important browse in the early spring.

The limiting factor for livestock production in the basins is stock water. There are natural springs, many of which are geothermal. At contact time, mountain men trappers traversing the region during the early 19th century reported that the vast valleys of northern Nevada were virtually devoid of native large herbivores. The extremely sparse native human population was dependent on grass seeds, occasional good crops on pinyon pine nuts, and jackrabbits for survival. It has been reported that rats cooked over a fire on a stick were a delicacy. Water development was a necessary precursor for domestic livestock production. Horses and sheep can survive on these ranges in the winter by eating snow for water, but cattle must have free water to drink. Following a substantial winter moisture event, desert-wise cows will range many miles from established watering points depending on mud puddles trapped in miniplayas for water while grazing only the dry inflorescence of Indian ricegrass to get the high protein content retained in the seed morphs. Cows will drink these puddles down until their own tracks are empty and then strike out across the desert to the next puddle.

The loosely defined "salt deserts" of Nevada are usually associated with the vast lake plains left by the pluvial lakes. W. D. Billings, in his pioneering studies of the Northern Carson
Desert, pointed out that much of what is called salt desert vegetation grows on soils that are not salt affected. These are alluvial fans and lower elevation mountain ranges where it is atmospherically so dry most of the woody sagebrush species cannot survive. The vegetation of these areas is often referred to as shadscale deserts, but the most abundant and largest woody species in stature is Bailey greasewood. Unlike the phreatophic black greasewood, this species is totally dependent on rain-fed moisture in an environment that struggles to average 4 to 5 inches of annual precipitation. This average precipitation is raised by occasional very wet winters ( 6 to 8 inches) interspersed by winters when virtually no moisture events occur. The major adaptive characteristic of the plants of this portion of the salt desert is endurance. Bailey greasewood plants will go years without flowering at a given site and in extreme cases go a year without leafing-out. In these communities most shrubs are gray with spine-tipped branches and grow on mini-mounds of trapped sand and silt.

The major forage and browse species of these aridity "salt desert" environments are Indian ricegrass, desert needle grass, winterfat, and bud sage. Both shadscale and greasewood have spine-tipped branches which restrict browsing. Greasewood browse is toxic in the spring (oxalate content) and mechanically injurious in the fall when the spines will penetrate the rumen walls. In the winter, cattle and sheep utilize the wind-dispersed fruits of shadscale and greasewood as an important protein source. Cowboys refer to this as "lickings" because cows will lick the windrows of fruits (urtricle) from the soil surface.

The transition from salt desert to sagebrush/bunchgrass zones can be very distinct, as in the high valleys of central Nevada where coalescing alluvial fans (bajadas) spilling down from the mountain escapements partially bury the lake plain and you can step from black greasewood-salt rabbitbrush to Wyoming big sagebrush/Thurber's needlegrass communities as the soils change. In other topoedaphic situations where the transition is gradually conditioned by effective moisture gradients, ragged infusions of big sagebrush into shadscale or the reverse occur. You can argue whether black sagebrush/bunchgrass communities represent the higher potential salt desert communities or the lower potential sagebrush/bunchgrass environments, but nonetheless, black sagebrush is a major browse species on winter ranges in Nevada. Black sagebrush is the only woody sagebrush species that can be a major part of the diet of domestic herbivores and especially wintering range sheep bands. Black is one of the low, or sometimes referred to as dwarf, sagebrush species in contrast to the much taller big sagebrushes which in Nevada are largely the subspecies basin, Wyoming, and mountain big sagebrush.

The big sagebrush subspecies combine with dominant perennial grasses to form a series of repetitive communities. In far northwestern Nevada, Columbia River basalt flows occur as an extension of eastern Oregon and the Pacific Northwest geology. Big sagebrush/bluebunch wheatgrass or big sagebrush/bluebunch wheatgrass-Idaho fescue communities 
dominate the landscape and appear very similar to the vegetation of eastern Oregon. For much of northern Nevada, the common long-lived perennial grass in the understory of big sagebrush communities is Thurber's needlegrass. The needlegrass tribe including Thurber's, Indian ricegrass, and needle-and-thread grass are much more significant in the rangelands of Nevada than the wheatgrasses. Another often overlooked perennial grass is basin wild rye. This mammoth statue bunchgrass with short rhizomes is the only grass that plays a significant role in the salt deserts on lake plains and the uplands through much of the pinyon-juniper zone.

The woody sagebrush species of Nevada do not sprout after the tops are burned in wildfires. This has major significance as the interval between returning wildfires has greatly decreased during the 20th century. Following wildfires, gray and green rabbitbrush, horsebrush, and ephedra species became the transitory woody dominants until sagebrush plant gradually reestablished as seedlings.

Sagebrush communities continue as understory species in the pinyon-juniper woodlands as you rise in elevation on Nevada mountain ranges. W. D. Billings pointed out in the mid-20th century that successionally all the pinyon-juniper communities arise through sagebrush/bunchgrass communities. During the 20th century, the pinyon-juniper woodlands both thickened in tree density and expanded both up and down slope. These woodlands provide much of the habitat for mule deer and Rocky Mountain elk in Nevada.

Above the pinyon-juniper zone and below the 5-needle pine zone there occurs on the mountains of Nevada a treeless zone that should support a forest of 3-needle pine and Douglas fir. For reasons that are not fully understood, this vegetation type was apparently lost early in the Pleistocene and remains treeless. With an abundance of antelope bitterbrush, snowberry, and serviceberry these sites, known as mountain brush communities, provide valuable summer range for wildlife and livestock.

To this point our discussion has considered the cold or more properly termed temperate deserts of northern and central Nevada. There are warm deserts in southern Nevada complete with creosote bush and Joshua trees as well as many of the species of the Mojave desert environment of southern California. A transitional zone characterized by blackbrush forms an irregular, discontinuous arch across Nevada between the temperate and warm desert environments. Sagebrushdominated communities persist on the high mountain ranges of southern Nevada. Galleta, a perennial grass characteristic of areas of the southwest with summer and winter precipitation periods, is widely distributed in southern Nevada and extends as far northwest as the drier portions of the Carson Desert.

Large-scale livestock ranching did not get started in northern Nevada until the 1870 s. It grew rapidly until the severe drought of 1888-1889 was followed by the extremely hard winter of 1889-1890. Some estimates place the cattle losses from this winter at $95 \%$ in northern Nevada. Out of the wreckage of this winter came the cattle production model that livestock operators need to produce 1 ton of hay for every cow wintered. Hay production was possible only on irrigated ground and only $5 \%$ of the landscape was applicable to irrigation because of the available water supply. To have a sufficient watershed to provide runoff to support irrigation you had to be located on a stream where the headwaters were near 10,000 feet in elevation. This limited irrigated agriculture to the forks and main trunk of the Humboldt River in the interior and the Susan, Truckee, Carson, and Walker Rivers that drained into the western portions of the state from the high Sierra Nevada. The early irrigation practices along these rivers essentially extend the spread and duration of the annual spring high-water flood. Termed "native hay meadows," these fields featured a mixture of native and introduced grasses, sedges, rushes, tules, and willows, all of which were cut for low-quality hay. Production from these meadows seldom exceeds 1 ton of hay per acre. Cattle were gathered off the range in the fall and turned on the meadows to graze crop aftermath. It generally has proven not to be economically feasible to greatly enhance the productivity of these meadows due to the nature of the soils, topography, and available water supply.

In 1903, the Federal government launched the Newlands Project located on the Carson River at Fallon, Nevada. Among the first of the desert reclamation projects in the American West, the Newlands Project changed the nature of the livestock industry because for the first time the state had a surplus of high-quality forage. It was soon discovered that alfalfa hay of exceptional quality could be produced at Fallon. For beef cattle production at the time, the product was 2- to 3 -year-old steers that were fattened on grass. To finish such animals you had to have rangelands capable of producing at least a pound of gain per day on steers. None of the upland Nevada rangelands were capable of producing this level of gain. The only option was irrigated meadows, and this option was all but impossible because the endemic disease "red water" was found on the meadows which infected animals through a liver fluke vector who spent part of its complicated life cycle in freshwater snails in the meadows. Finish-

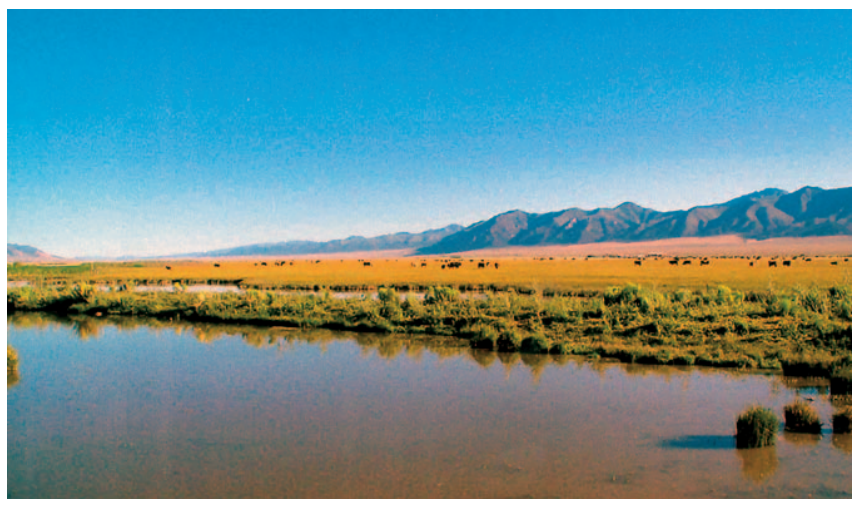

It is hard to believe that the deserts of Nevada actually have wet meadows. This image was taken in Reese River Valley looking towards the Shoshone Mountains. Until a vaccine was developed for red water disease, these meadows were not safe to graze. 


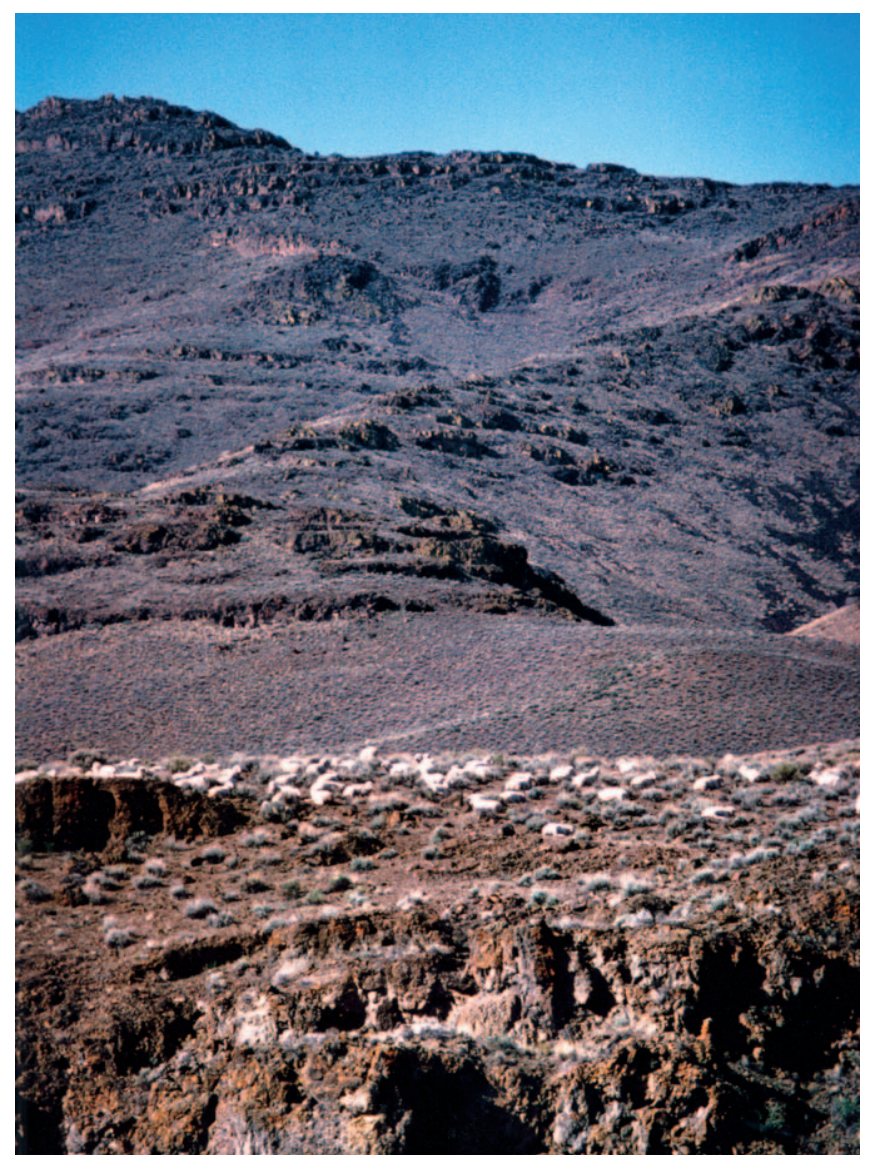

During the first half of the 20th century, Nevada had a huge range sheep industry. After World War II, the poisonous plant halogeton, labor supply problems, predators, and image associations combined to make the sheep business unpopular. Sheep are more adapted to the browse and forage of desert ranges than cattle and have much better water relations.

ing steers on hay and grain produced under irrigation on the Newlands project made the livestock industry viable for the first half of the 20th century.

After the disaster of the hard winter of 1889-1890, the range sheep industry grew rapidly in Nevada. You did not have to have hay to winter sheep on the range. No hay meant you did not have to own irrigatable hay meadows. Sheep did not have to drink water on the winter ranges if snow or even abundant frost was available. The range was free for the taking. The Federal government maintained ownership of 87\% of the land in Nevada. The Central Pacific Rail Road Grant constituted nearly $5 \%$ of the land area of the state and very little of this land was sold to ranchers and potential settlers. Nevada gave its sections 16 and 36, the land grant school support sections, back to the Federal government because it could not sell them. Congress allowed the State of Nevada to sell 2 million acres of buyer-selected land in 40-acre parcels in lieu of the school sections. Most of these 40-acre parcels went for hay production land or were located around springs.

A large range sheep industry developed in Nevada where the sheep operations owned no base property and depended on the open Federal rangeland for forage year around. Despite the lack of trees in Nevada, National Forests were es- tablished in Nevada, at least partially because of the political power of large cattle ranches who hoped the Federal agency would exclude what was termed tramp sheep operations. The bulk of the rangelands of Nevada remained open range with no control until the Grazing Service was established in 1936. The last Grazing District was not established in Nevada until the 1950s when the Grazing Service had been integrated into the Bureau of Land Management (BLM), US Department of Interior. Soon after the formation of the Grazing Service a meeting was held in Reno to try and determine who claimed what grazing land. In response to the question of where the northern limit of his range was located one rancher replied, "the Canadian line." The examiner asked, "I suppose you claim the border with Mexico to the south?" With a straight face the rancher replied, "No, I go just north of Mexico City."

The first half of the 20th century was not kind to Nevada rangelands. The native perennial bunchgrasses that provided the bulk of the forage from the range were highly susceptible to overgrazing if they were grazed starting in the early spring by excessive numbers of livestock and the grazing continued season long year after year. The grazing was on a community allotment basis. If you tried to graze responsibly and leave a reserve of herbage for the plants, the neighbor you had not spoken to for 15 years pounced on the range and grazed it into the ground or worse yet it attracted a tramp sheep outfit.

By post-World War II, Life magazine ran a photo-journalism artice on Elko, Nevada. Bold type words proclaimed the only thing in short supply was $\$ 100$ bills. Beef, mutton, and wool prices went sky high when price-control measures imposed during the war were lifted. California movie stars were buying big ranches. The local casinos had started a practice of importing big name entertainers to attract customers. The livestock industry of Nevada was about to go for a big fall. Beef prices took a tremendous drop in 1950 despite the Korean War. Life magazine ran an article showing hundreds of dead sheep. A new weed named halogeton was ruining the range sheep industry. The Federal government had to do something immediately.

Marion Clausen was Director of the Bureau of Land Management. He was a man of uncommon vision. He had been born and spent his early years in Elko County. He correctly identified the concept that halogeton was not the disease (with the help of some of the outstanding university professors of range management at the time), but rather a symptom of ranges with excessive numbers of livestock and no management. During the 1930s a group of scientists employed by the Intermountain Forest and Range Experiment Station of the Forest Service, US Department of Agriculture, had perfected methodology for successfully establishing crested wheatgrass on degraded former big sagebrush/bunchgrass ranges. Clausen realized he did not have the political clout to cut the numbers of livestock permitted on BLM lands. Instead he treated the "halogeton disease" by increasing the forage base through establishing crested wheatgrass seedings 
on single permitee grazing allotments. In return for getting the BLM to pay for crested wheatgrass seeding, the permitee had to agree to management concessions that often reduced the numbers of animals allowed to graze or at least the total number of animal unit months that could be grazed.

Federal agencies and private landowners converted 1 million acres of the 19 million acres of big sagebrush/bunchgrass potential plant communities in Nevada to crested wheatgrass seedings. It is estimated that this 1 million seeded acres of crested wheatgrass, $3 \%$ of the area, provided $25 \%$ of the range forage base for the Nevada livestock industry. Moreover, it provided forage in the early spring that was sustainable when native grasses were most susceptible to damage from grazing. The crested wheatgrass seeding program was dropped in the mid-1960s because of costs, conflicts with recently passed national environmental laws, and the apparent belief that the problems with Nevada rangelands could be solved by applying a single form of grazing management, rest-rotation grazing.

There seems to be a general apathy towards comprehensively evaluating massive applications of technology to rangelands. Chaining pinyon-juniper woodlands or rest-rotation grazing are probably the largest consciously applied vegetation treatments ever applied to rangelands in the world, but consequences of these actions in entirety seem lost in bureaucratic smoke and mirrors. The comprehensive independent evaluation of large-scale range improvements done in the Vale Project by Heady and Bartholomew is an exception. It is a report well worth reading.

Grazing management occupied a cornerstone position in range management education during much of the 20th century. Wayne Burkhardt was the first to have the clarity of vision to recognize that rest-rotation grazing management on Nevada rangelands was an environmental disaster where the exotic, highly invasive annual cheatgrass was the primary forage. Dr. Burkhardt was also among the first to have the intestinal fortitude to express this view in public.

Cheatgrass increases the chance of ignition, provides the continuity of fuel to increase rate of spread, and extends the wildfire season to the warmest months of the summer. The net result is on certain years when herbage production of cheatgrass vastly exceeds the number of grazing animals, and the right timing and intensity of fire ignition happens (dry lighting storm), a firestorm occurs that is impossible to suppress. In 1999 an estimated 1.8 million acres of rangelands burned in northern Nevada. In 2005 a million acres burned in southern Nevada as a result of red brome as a fuel source. We know the way to suppress the exotic annual grasses is to establish and correctly manage perennial grass stands. Unfortunately, the establishment of perennial grass seedlings in the face of cheatgrass competition is very difficult. If the policy is that only seeds of native grasses can be used on Federal lands, establishment at this time is impossible.

The million acres of degraded big sagebrush/bunchgrass that was converted to crested wheatgrass in Nevada is now largely converted back to big sagebrush with the crested

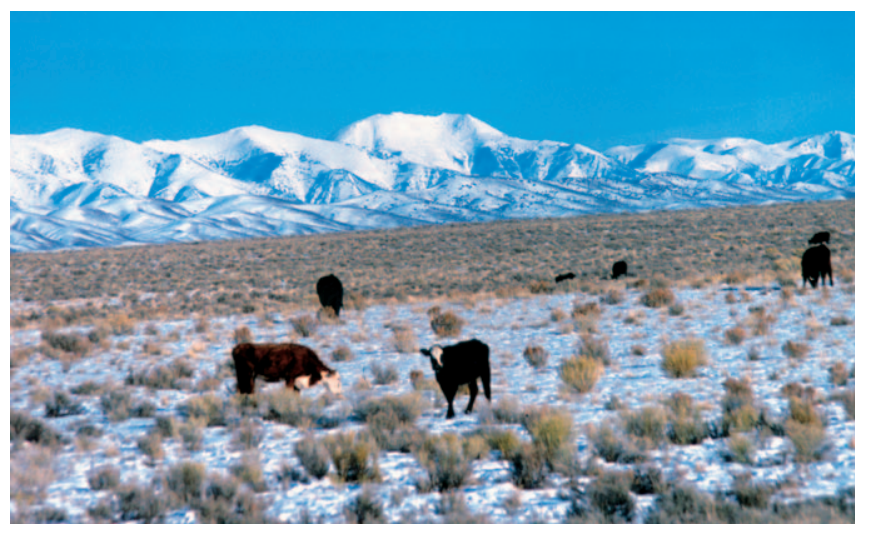

During the last couple of decades many progressive ranchers have experimented with winter grazing in cooperation with the Bureau of Land Management. There is a risk to winter grazing, but there are also great cost savings because of the capital and labor associated with spending half the year growing and cutting hay and the other half feeding cows. There are biological advantages to grazing plants while they are dormant. Several of the native perennial grasses are very susceptible to grazing during the spring.

wheatgrass barely surviving and having minimal forage production. Unless a balance between the shrubs and perennial grasses is returned by range improvement practices such as prescribed burning or herbicide application, the perennial grasses will be lost and replaced by cheatgrass. The dominance of cheatgrass in the understory will lead to wildfires destroying the sagebrush and cheatgrass inheriting the sites.

It is not all doom and gloom on Nevada rangelands. At higher elevations, with higher environmental potential, grazing management has brought back native perennial grasses to the point that wildfires are occasionally burning in native grasslands. Shinn Peak of the Nevada-California border is a good example. There has been an increase in winter grazing combined with switching native hay meadows to pastures for early weaning of calves. This switch breaks the production model of 1 ton of hay per brood cow established after 1890 . A winter as severe as 1889-1890 may reoccur, but it has not for more than a century. Winter grazing is complementary with the physiology of native perennial grasses such as basin wild rye which are not too resistant to grazing during the growing season.

The problems of Nevada rangelands and the range livestock industry are obviously daunting, but they mirror the status of rangelands on a worldwide basis. Different environments have variations in the pressing problems, but there is no shortage of problems. The 2007 annual meeting of the Society for Range Management provides the opportunity for all interests, ranchers, Federal land managers, and anyone interested in the desert environments to participate through presentations and discussions in developing innovative approaches to the management of rangelands.

Authors are Range Scientists, US Department of Agriculture, Agricultural Research Service 920 Valley Road, Reno, NV 89512, jayoung@scs.unr.edu,charlie@scs.unr.edu 